\title{
First report of pigmentation dystrophy in terrestrial isopods, Atlantoscia floridana (van Name) (Isopoda, Oniscidea), induced by larval acanthocephalans ${ }^{1}$
}

\author{
José F. R. Amato ${ }^{2}$, Suzana B. Amato ${ }^{2}$, Paula B. Araujo ${ }^{2} \&$ Aline F. Quadros ${ }^{2}$ \\ ${ }^{1}$ Contribution number 394 of the Departmento de Zoologia, Universidade Federal do Rio Grande do Sul. \\ 2 Departamento de Zoologia, Instituto de Biociências, Universidade Federal do Rio Grande do Sul. Av. Bento Gonçalves 9500 , \\ prédio 43435, 91501-970 Porto Alegre, Rio Grande do Sul, Brasil. E-mail: jfamato@terra.com.br, sbamato@vortex.ufrgs.br, \\ pbaraujo@portoweb.com.br; and bioaline@terra.com.br
}

\begin{abstract}
The observation of pigmentation alteration in isopod crustaceans induced by acanthocephalans, known as pigmentation dystrophy, has been documented in North America in species of the aquatic genera Asellus Geoffroy, 1764, Lirceus Rafinesque-Schmaltz, 1820, and Caecidotea Packard, 1871, and in Europe, in Asellus. Recently, three depigmented specimens of Atlantoscia floridana (van Name, 1940), a terrestrial isopod, occurring from Florida, USA to northern Argentina were found showing pigmentation dystrophy and harboring larval acanthocephalans. Photographic documentation of live and preserved, infected isopods is presented. Morphometric data and photomicrographs of the male, unencysted cystacanth specimen which allowed its placement in the genus Centrorhynchus Lühe, 1911 are presented. This is the first record of the phenomenon of pigmentation dystrophy in terrestrial isopod crustaceans, the first record of $A$. floridana infected by an acanthocephalan and the first record of a species of Centrorhynchus in a terrestrial isopod.
\end{abstract}

KEY WORDS. Crustacea, cystacanth, intermediate hosts, pigmentation alteration, southern Brazil.

Acanthocephalans as adults are intestinal parasites of vertebrates, and their life cycle includes arthropods as intermediate hosts where their larvae, acanthellae and cystacanths, develop. Occasionally vertebrates participate in the life cycle as paratenic hosts harboring cystacanths. The paratenic hosts will serve as a trophic bridge between the intermediate and the definitive hosts carrying the cystacanths to the definitive host.

Pigmentation alteration of isopod and amphipod crustaceans induced by larval acanthocephalans, known as "color dichromatism", "depigmentation", "non-pigmentation", or more properly, "pigmentation dystrophy", as suggested by Oetinger \& Nickol (1981), has been documented for North America in species of the aquatic isopod genera Asellus Geoffroy, 1764, by Seidenkerg (1973), CAmp \& Huizinga (1979) and Oetinger \& Nickol (1981, 1982); Lirceus Rafinesque-Schmaltz, 1820, by Oetinger \& Nickol (1981, 1982), and Caecidotea Packard, 1871, by Oetinger (1987). Dezfuli et al. (1994), documented this alteration in Europe, also in species of Asellus.

In terrestrial isopods, Moore (1984) has pointed out that Armadillidium vulgare (Latreille, 1804) infected with cystacanths of Plagiorhynchus cylindraceus (Goeze, 1782) did not show pig- mentation dystrophy, but displayed behavior alterations. SidDikov (1987) reported a species of Hemilepistus Budde-Lund, 1885 and a species of Porcellio Latreille, 1804 as being infected by cystacanths of Centrorhynchus lanceoides (Petrochenko, 1949), which Golvan (1956) had transferred to his newly erected genus Sphaerirostris Golvan, 1956, but did not mention any alteration concerning pigmentation and behavior. So, terrestrial isopods, up to the present, had not been found displaying pigmentation dystrophy induced by larval acanthocephalans.

Atlantoscia floridana (van Name, 1940), a terrestrial isopod of the family Philosciidae, has a wide, known geographical distribution (Florida, USA to northern Argentina) (LeISTIKow $\&$ WäGELE 1999). This species of woodlouse is found in practically all Brazilian coastal states, and, according to LEMOS DE CASTRo (1985), is the predominant isopod in the habitats where it occurs.

The present paper registers for the first time the phenomenon of pigmentation dystrophy induced by larval acanthocephalans in terrestrial isopods, and $A$. floridana harboring a larval acanthocephalan of the genus Centrorhynchus Lühe, 1911.

Revista Brasileira de Zoologia 20 (4): 711-716, dezembro 2003 


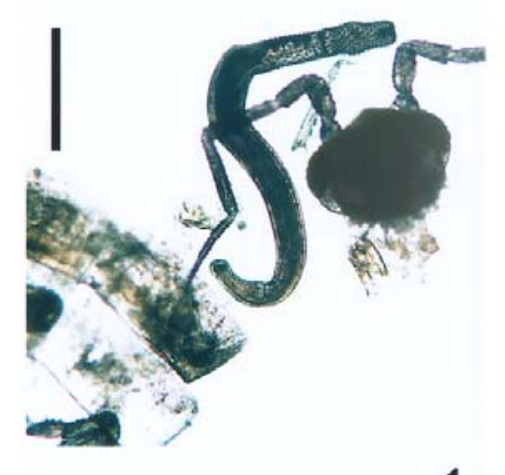

1

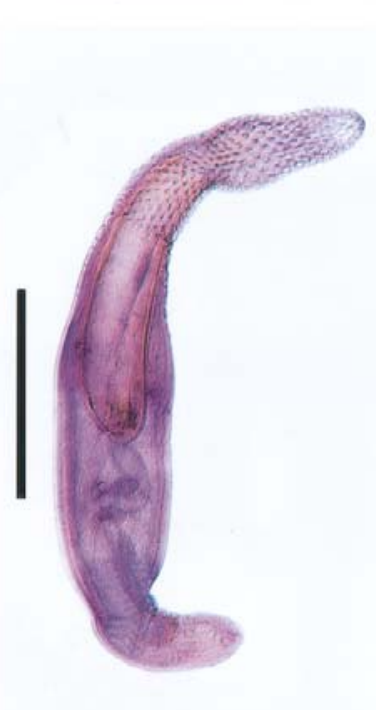

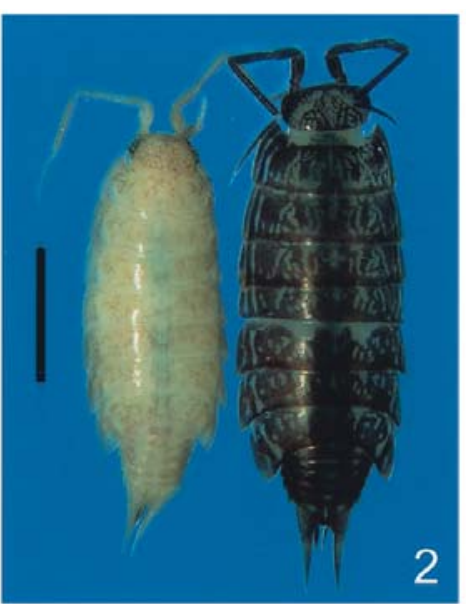
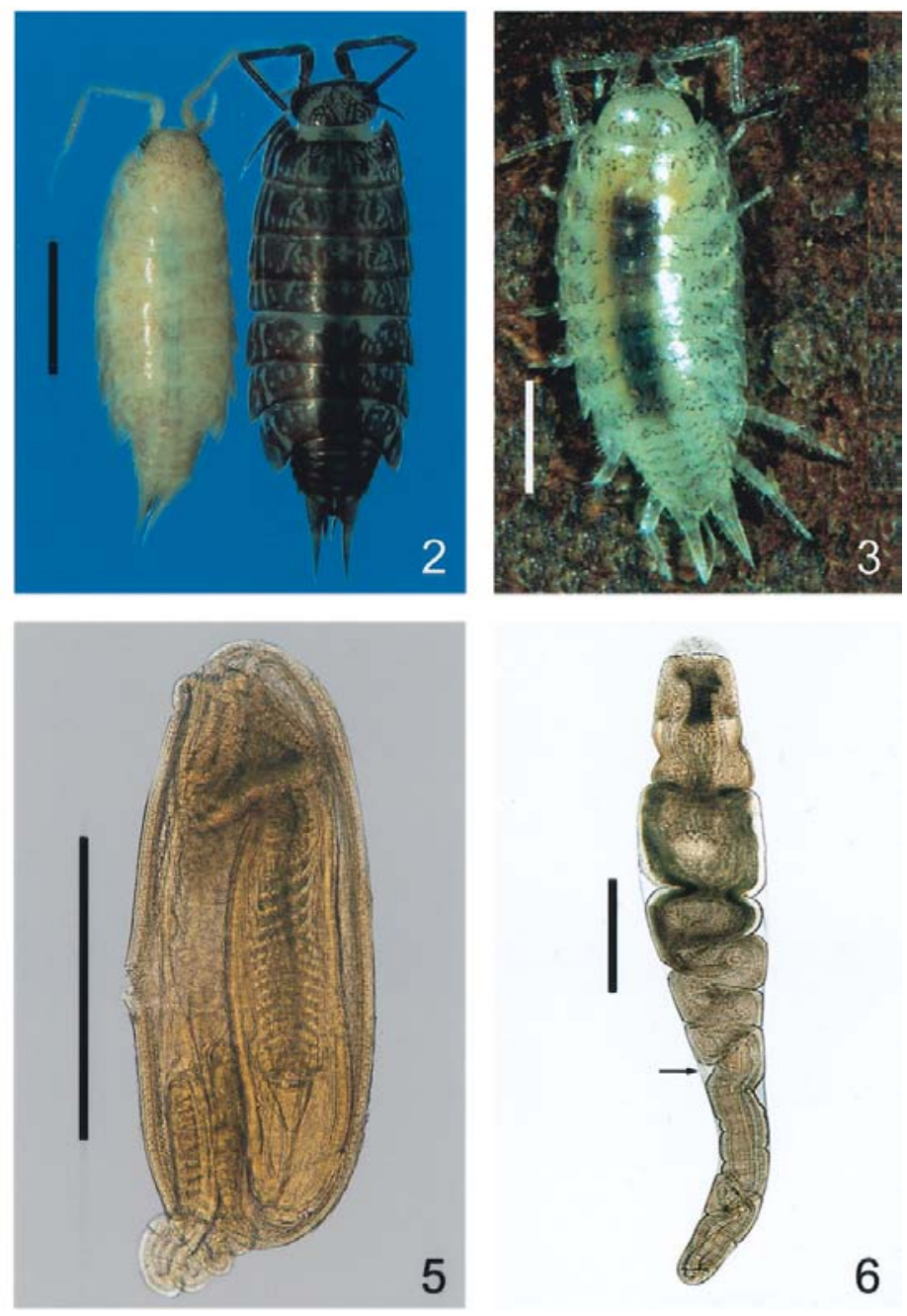

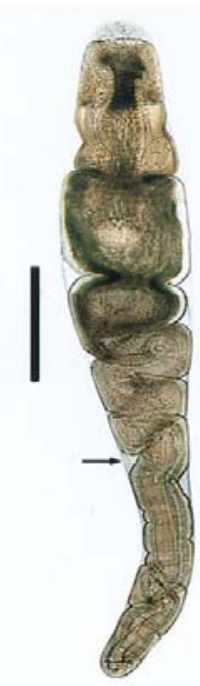

6

Figures 1-6. Atlantoscia floridana, infected and uninfected and cystacanths of Centrorhynchus sp.: (1) live, unencysted cystacanth of Centrorhynchus sp., head with antennae and two unpigmented pereionites of $A$. floridana, bar $=1 \mathrm{~mm}$; (2) fixed, infected specimen (left) showing pigmentation dystrophy and uninfected specimen (right) of $A$. floridana, $\mathrm{bar}=2 \mathrm{~mm}$; (3) live, infected specimen of $A$. floridana, showing pigmentation dystrophy, bar $=1 \mathrm{~mm}$; (4) unencysted cystacanth of Centrorhynchus sp., from A. floridana, stained in Delafield's hematoxylin, bar $=1 \mathrm{~mm}$; (5) encysted cystacanth of Centrorhynchus sp., cleared in Amann's lactophenol; (6) live, unstained, encysted cystacanth of Centrorhynchus sp., showing envelope of parasite origin (arrow), bars $=500 \mu \mathrm{m}$.

\section{MATERIAL AND METHODS}

More than 8000 specimens of $A$. floridana, collected between 1990 and 2002, were examined for pigmentation dystrophy, in southern Brazil, including many localities in the states of Santa Catarina and Rio Grande do Sul (map in Araujo et al. 1996). The three depigmented isopods were collected, two of them on the Campus of the Universidade Federal do Rio Grande do Sul (UFRGS), Porto Alegre, Rio Grande do Sul, Brazil, $\left(30^{\circ} 03^{\prime} \mathrm{S}, 51^{\circ} 07^{\prime} \mathrm{W}\right)$, in November 2001 and September 2002 , respectively, and the other depigmented specimen was collected in the coast town of Rondinha, Rio Grande do Sul. The larvae were fixed in AFA (Ethanol, Formalin, Glacial Ace- tic Acid) and stained in Delafield's hematoxylin (Humason 1979). Four hundred and twenty six pigmented specimens of A. floridana were also examined after clarification in Amann's lactophenol. Measurements are in micrometers $(\mu \mathrm{m})$, unless otherwise indicated; averages follow ranges within parentheses; widths were taken at widest point. All measurements for proboscis hooks were made in full lateral profile. The only unencysted cystacanth was deposited in the Coleção Helmintológica do Instituto Oswaldo Cruz (CHIOC), Rio de Janeiro, State of Rio de Janeiro, Brazil (Catalog No: 36196 male); the infected isopods were deposited in the Coleção de Crustáceos, Departamento de Zoologia, UFRGS (Catalog $\mathrm{N}^{\circ}$ : 3551 female, 2507 male and 3552 female). The pigmented, 
uninfected specimens of $A$. floridana were also deposited (Cata$\left.\log \mathrm{N}^{\circ} 3553\right)$. Four adult specimens of $C$. tumidulus deposited in the CHIOC $\mathrm{N}^{\circ} 1899,1900,1901$, and 1902, were examined.

\section{RESULTS}

Three specimens of $A$. floridana were found with pigmentation alteration. The first and the third specimens (Figs 1 and $3)$, collected alive during litter triage, showed pigmentation dystrophy in the head, pereionites and pereiopods. It was possible to see the faint, irregular pigmented areas as well as the dark contents (food) in the digestive system. The second isopod with pigmentation alteration (Fig. 2, left) was found fixed in ethanol, among many others with the normal, dark pigmentation, deposited in the crustacean collection (Fig. 2, right).

Upon dissection, all the isopods with pigmentation alteration were found to harbor one larval acanthocephalan (cystacanth) each, in the hemocoel of the pereion. The 426 isopods with normal pigmentation collected from the same location as the first and third specimens, were negative for larval acanthocephalans.

The live, unencysted cystacanth (Figs 1 and 4), was whitish and moved actively, it had the proboscis inserted in tissues of the anterior region of the hemocoel. The second fully encysted cystacanth (Fig. 5) could not be removed from the cyst because the isopod was already fixed in ethanol. The third cystacanth, alive at dissection of the host, was whitish and recently encysted having only the envelope of parasite origin (Fig. 6, arrow).

The cystacanths found clearly belong to Centrorhynchus by having the typical proboscis of the genus, with three portions, the middle one inflated, and a constriction at the insertion of the proboscis receptacle (Fig. 7).

The unencysted cystacanth (Figs 1 and 4) was a male specimen: trunk cylindrical, tapering anteriorly, widest at level of the proboscis receptacle, inflated, anterior portion $1.57 \mathrm{~mm}$ long, 530 wide; narrower, invaginable (in cystacanths and juveniles) posterior portion, called "hindtrunk" from now on (Figs 13-14), was 550 long, 294 wide. Middle third of proboscis inflated, with the largest hooks, tapering anteriad, with a constriction at receptacle insertion, $1.04 \mathrm{~mm}$ long [229 wide in anterior third; 330 wide in middle third (at inflation); 250 wide at receptacle insertion; 330 wide in posterior third (at base)], with 28 rows of 20-22 hooks each, 9 are rooted hooks and 13 are rootless spines. Anterior 1-2 hooks in each row 5-7.5 long, anterior manubrium present; next 4-5 hooks with simple roots. Apical hooks 30-40 (37) long; remainder 32.5-37.5 (35.6) long. Spines 22.5-27.5 (25.2) long. Roots of largest hooks 45-57.5 (53.1) long. Neck short, not measurable in this specimen. Proboscis receptacle double-walled, extending to equator of the inflated portion of the trunk, 870 long, 224 wide; proboscis ganglion ellipsoid, just bellow the line between neck and trunk. Lemnisci with approximately equal lengths, shorter than proboscis receptacle, 700 and 750 long, respectively. Testes ellipsoid, in tandem, between middle and posterior thirds of the inflated portion of the trunk; anterior testis 170 from the bottom of proboscis receptacle.

The live encysted cystacanth (Fig. 6) was photographed and measured before fixation. It was $3.13 \mathrm{~mm}$ long, 445 wide (maximum width). The second, fixed, encysted cystacanth was 959 long, 392 wide (maximum width).

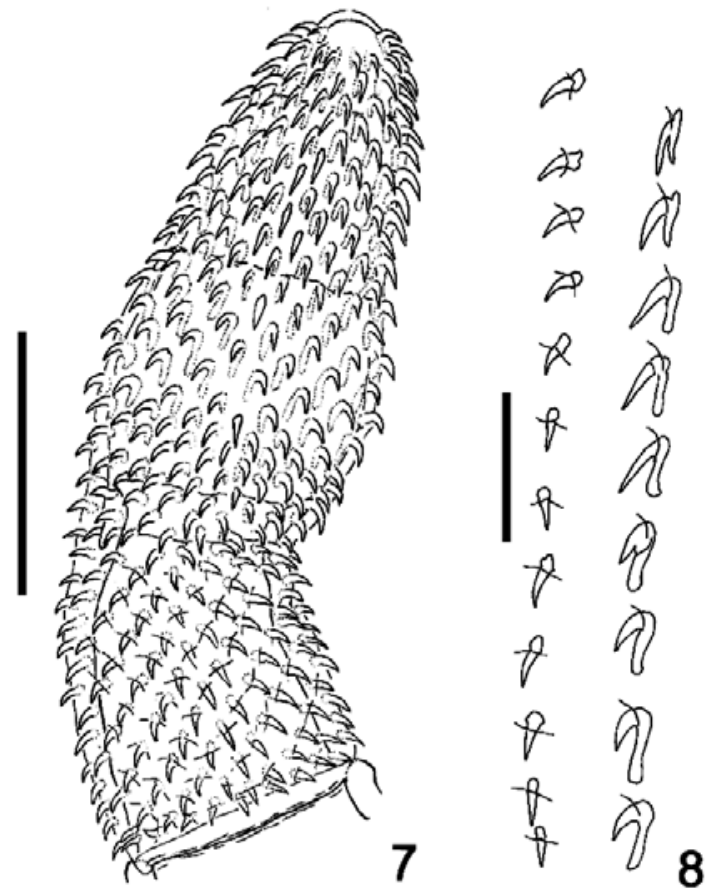

Figures 7-8. Centrorhynchus sp. from Atlantoscia floridana: (7) proboscis, bar $=500 \mu \mathrm{m} ;(8)$ one longitudinal row with 9 hooks and 12 spines, bar $=100 \mu \mathrm{m}$.

\section{DISCUSSION}

The effects of acanthocephalans on their intermediate hosts were discussed by various authors and range from increased conspicuousness, either by the larvae acquiring pigmentation or by pigmentation dystrophy of the host, which results from the interference of the acanthocephalan with the metabolic pathway for ommochrome pigmentation in the isopod hosts (Oetinger \& Nickol 1982) to castration. Recently FulLer et al. (2003) reported pigmentation and behavior alteration in termites due to acanthocephalans.

Yamaguti (1963) listed four species of Centrorhynchus as parasites of birds in Brazil. AmIN (1985) included 75 species in Centrorhynchus, most of them parasites, as adults, in birds of prey of the orders Falconiformes and Strigiformes, and, more rarely, in mammals. RichaRdson \& Nickol (1995) have added one more species of Centrorhynchus parasite of owls for North America. DE Buron \& Golvan (1986) have listed the known intermediate hosts of acanthocephalans and indicated only three species of terrestrial isopods of the genera Armadillidium Brandt, 1833 and Porcellio as intermediate hosts for $P$. cylindraceus. Centrorhynchus and Sphaerirostris were indicated, generically, as having terrestrial isopods and insects (one unconfirmed record) as intermediate hosts in their life cycles. Scнмidt (1985) has indicated only one intermediate host for species of Centrorhynchus, and even so, it was an orthopteran of the superfamily Acridoidea, not a crustacean.

Travassos (1926), revising the Centrorhynchinae listed the following species of Centrorhynchus as occurring in Brazil: C. tumidulus (Rudolphi, 1819), C. giganteus Travassos, 1921, C. 

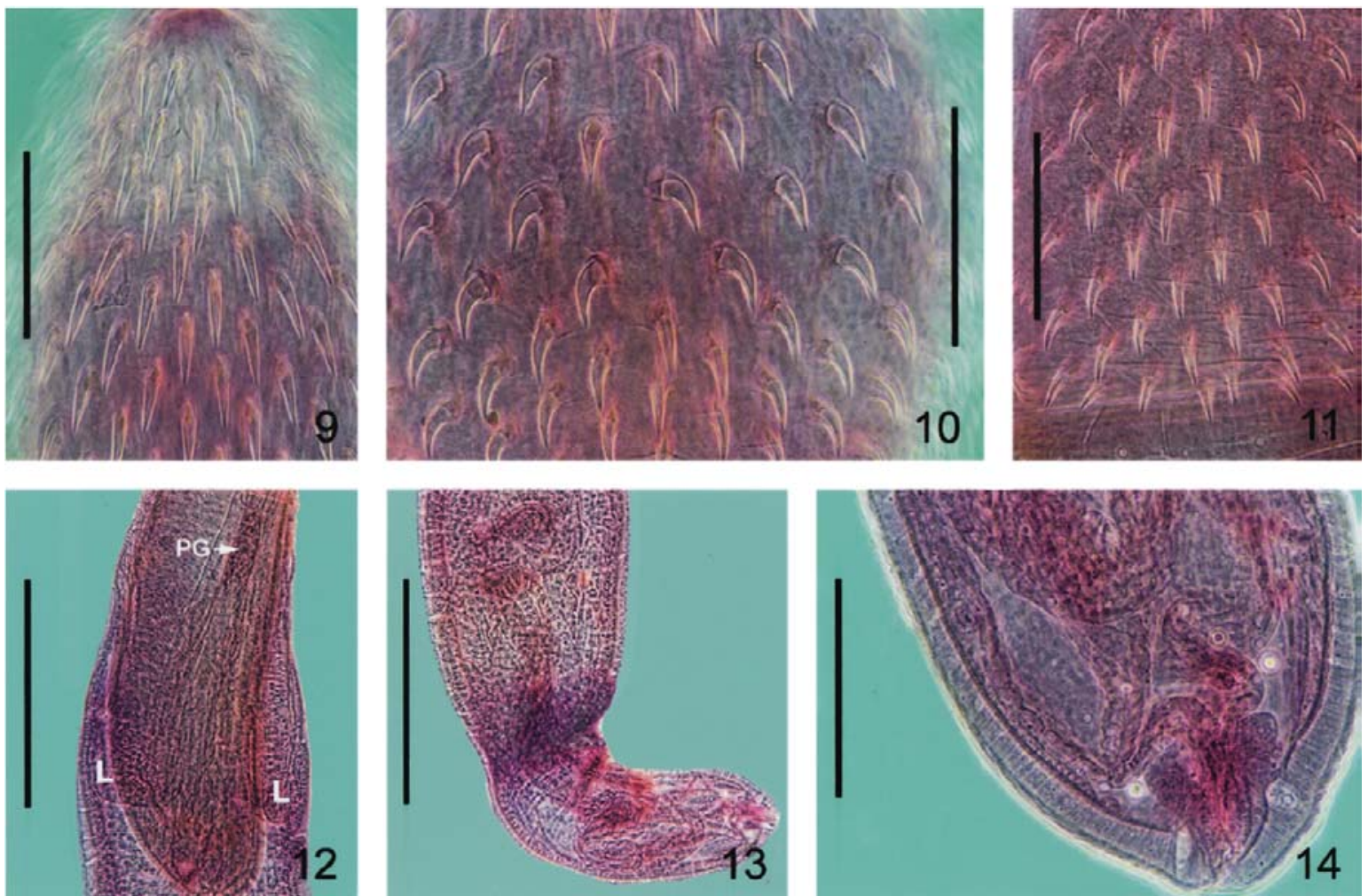

Figures 9-14. Centrorhynchus sp., from Atlantoscia floridana: (9-11) anterior, middle (inflated) and posterior thirds of proboscis, respectively (phase contrast), bars $=125 \mu \mathrm{m}$; (12) proboscis receptacle with proboscis ganglion (PG) and lemnisci (L); (13) middle portion of trunk, showing testes and hindtrunk (phase contrast); (14) distal portion of hindtrunk, showing invaginated copulatory bursa (phase contrast), bars $=500 \mu \mathrm{m}$.

opimus Travassos, 1925, later transferred to Sphaerirostris, C. polymorphus Travassos, 1925 and Centrorhynchus sp. of JoHnston (1916). He indicated that these species use paratenic hosts (amphibians and reptiles) for the cystacanths, not mentioning any intermediate hosts.

Rodrigues (1970) has recorded encysted cystacanths of an undetermined species of Centrorhynchus, in the common gecko, Hemidactylus mabouia (M. de J.) from the city of Rio de Janeiro, while DE FABIO (1982) recorded encysted cystacanths of Centrorhynchus sp. in several species of three genera of Leptodactylinae from the rural area of the city of Rio de Janeiro.

The CHIOC does not hold any cystacanth of Centrorhynchus spp. from intermediate hosts. So far, all records of cystacanths attributable to the genus Centrorhynchus were made in paratenic hosts, amphibians and reptiles. A survey of all deposited cystacanths in the CHIOC showed 17 lots with indication of amphibians [6 records for Leptodactylus ocellatus (Linnaeus, 1758) and 3 records for Hyla sp.] and reptiles [3 records, generically referred as snakes, 2 for Drymobius bifossatus ( = Mastigodryas bifossatus (Raddi, 1820)], 1 for Herpetodryas sexcarinatus [incorrectly identified, being either Pseustes sexcarinatus (Wagler, 1824) or Chironius carinatus (Linnaeus, 1758)], both occurring in southeastern Brazil, and 1 for Ameiva ameiva (Linnaeus, 1758) (today considered a complex formed by many subspecies) as paratenic hosts. Torres \& Puga (1996) and Puga \& Torres (1999) recorded encysted cystacanths in paratenic hosts from Chile, which they identified as Centrorhynchus sp., although their drawings show that the acanthocephalans might belong to Sphaerirostris for having the proboscis with a spherical anterior portion and a larger number of hooks in the longitudinal rows.

Comparing the shape and oncotaxy of the proboscis of the larvae found in A. floridana (Figs 4, 8-11) with that reported from H. mabouia (paratenic host) in Rio de Janeiro by RoDRIGUES (1970) is possible to see that the shape of the proboscis is markedly different, being wider in the anterior third, while that reported by DE FABIO (1982) is more similar by having the proboscis with an inflated middle third and a short hindtrunk, but still having the apical third of the proboscis wider than that being presently reported.

Comparing the proboscis of adult $C$. tumidulus in the male specimen (CHIOC $\mathrm{N}^{\circ} 1899$ ) and those in the slides CHIOC $\mathrm{N}^{\mathrm{o}} 1900,1901,1902$, all collected from "anu-preto" or "ani" Crotophaga ani (Linnaeus, 1758) (Aves, Cucculidae), in Rio de Janeiro by Dr. Lauro Travassos, with that found in A. floridana (Figs 4, 7, 9-11) is possible to see differences which do not warrant the specific determination of the present specimen as C. tumidulus. The proboscides differ in size, although the ante- 
rior third is slender and the middle third is inflated, the hooks in the apical third are stouter, having a wider base $(11 \mu \mathrm{m})$ and shorter blade $(34 \mu \mathrm{m})$ in the adult specimens (CHIOC 1899), while the spines are longer $(12 \mu \mathrm{m})$. The hindtrunk of the cystacanth found in the third dystrophic specimen of $A$. floridana (Fig. 6), collected from the same area as the first, is much longer (Fig. 4). The hindtrunk of the specimens of $C$. tumidulus (CHIOC $\mathrm{N}^{\circ} 1899$ ) is markedly longer $(8.25 \mathrm{~mm}$ and $9.12 \mathrm{~mm}$ in the male and the female specimens, respectively). There must be a pronounced allometric growth of this region of the trunk after the cystacanth infects the final host, in this case Crotophaga ani.

The comparison of C. albidus Meyer, 1933, from an unidentified falconid bird of Paraguay, shows that although the number of longitudinal rows of hooks and the number of hooks in each longitudinal row are similar, the oncotaxy and general appearance of the proboscides are different: nine rooted anterior hooks and 12 posterior, rootless spines in our specimen and seven anterior, rooted hooks and 13 posterior, rootless spines in C. albidus, allows the separation of both species. In addition, the lemnisci are shorter than the proboscis receptacle in present cystacanth specimen and much longer, reaching the anterior testis, in C. albidus. Having only one cystacanth specimen with the everted proboscis from these three isopods makes it impossible to appreciate any intraspecific variation and to ascertain the specific identity of these larvae.

Experiments will be conducted with specimens of $A$. floridana raised on a regular basis in the Carcinology Laboratory to provide more cystacanths for study and to induce pigmentation dystrophy in crustaceans of different age classes, in addition to allow experimental infections of definitive hosts.

\section{ACKNOWLEDGEMENTS}

To Drs. Dely Noronha, Luís Cláudio Muniz Pereira and Marcelo Knoff for lending specimens of C. tumidulus, for sharing survey data on the deposited specimens of $C$. tumidulus and listing of cystacanths from paratenic hosts deposited in the CHIOC, Instituto Oswaldo Cruz - FIOCRUZ, Rio de Janeiro; to Dr. Brent B. Nickol, School of Life Sciences, The University of Nebraska, for discussing the absence of records of parasitism in A. floridana; to Ronald D. Rocco, M. A., of Battle Creek, MI, for critically revising the English version of the manuscript and to Dr. Thales de Lema, Museu de Ciências e Tecnologia, Porto Alegre, Rio Grande do Sul, for the information on the nomenclature of reptiles.

\section{REFERENCES}

Amin, O.M. 1985. Classification, p. 27-72. In: D.W.T. Crompton $\&$ B.B. Nickol (Eds). Biology of the Acanthocephala. Cambridge, Cambridge University Press, XI+519p.

Araujo, P.B.; L. Buckup \& G. Bond-Buckup. 1996. Isópodos terrestres (Crustacea, Oniscidea) de Santa Catarina e Rio Grande do Sul, Brasil. Iheringia, Ser. Zool., Porto Alegre, (81): 111138.

Camp, J.W. \& H.W. Huizinga. 1979. Altered color, behavior and predation susceptibility of the isopod Asellus intermedius infected with Acanthocephalus dirus. Journal of Parasitology, Lawrence, 65 (4): 667-669.

DE Buron, I. \& Y.J. Golvan. 1986. Les hotes des acanthocéphales.
I - Les Hôtes intermédiaires. Annales de Parasitologie Humaine et Comparée, Paris, 61 (5): 581-592.

DE FabIO, S.P. 1982. Helmintos de populações simpátricas de algumas espécies de anfíbios anuros da família Leptodactylidae. Arquivos da Universidade Federal Rural do Rio de Janeiro, Seropédica, 5 (1): 69-83.

Dezfuli, D.F.; E. Rossetti; A. Fano \& R. Rossi. 1994. Occurrence of larval Acanthocephalus anguillae (Acanthocephala) in the Asellus aquaticus (Crustacea, Isopoda) from River Brenta. Bollettino di Zoologia, Modena, 61: 77-81.

Fuller, C.A.; P. Rock \& T. PHILIPs. 2003. Behavior, color changes, and predation risk induced by acanthocephalan parasitism in the Caribbean termite Nasutitermes acajutlae. Caribbean Journal of Science, Mayagüez, 39 (1): 128-135.

Golvan, Y.J. 1956. Le genre Centrorhynchus Lühe, 1911 (Acanthocephala, Polymorphida). Revision des espèces européennes et description d'une nouvelle espèce africaine parasite de Rapace diurne. Bulletin de l'Institute Français d'Afrique Noire, Dakar, Ser. A, 18: 732-791.

Humason, G. 1979. Animal Tissue Techniques. San Francisco, W.H. Freeman, $4^{\text {th }}$ ed., XIV+661p.

Johnston. H. 1916. A census of the endoparasites recorded as occurring in Queensland, arranged under their host. Proceedings of the Royal Society of Queensland, South Brisbane, 28: 31.

LeistiKow, A. \& J.W. WäGele. 1999. Checklist of the terrestrial isopods of the new world (Crustacea, Isopoda, Oniscidea). Revista Brasileira de Zoologia, Curitiba, 16 (1): 1-72.

Lemos de Castro, A.L. 1985. Considerações sobre Atlantoscia alceui Ferrara and Taiti, 1981 (Isopoda: Oniscidea: Philosciidae). Revista Brasileira de Biologia, Rio de Janeiro, 45 (4): 417-422.

Moore, J. 1984. Altered behavioral responses in intermediate hosts - An acanthocephalan parasite strategy. American Naturalist, Chicago, 123: 572-577.

Oetinger, D.F. 1987. Effects of Acanthocephalus dirus (Acanthocephala) on morphometrics and reproduction of Caecidotea intermedius (Crustacea: Isopoda). Transactions of the American Microscopical Society, Lawrence, 106 (1): 240-248.

Oetinger, D.F. \& B.B.Nickol. 1981. Effects of acanthocephalans on pigmentation of freshwater isopods. Journal of Parasitology, Lawrence, 67 (5): 672-684.

. 1982. Developmental relationships between acanthocephalans and altered pigmentation in freshwater isopods. Journal of Parasitology, Lawrence, 68 (3): 463-469.

PugA, S. \& P. Torres. 1999. Helminths parasites of Eupsophus roseus (Anura: Leptodactylidae) from southern Chile. Memórias do Instituto Oswaldo Cruz, Rio de Janeiro, 94 (6): 725-726.

RichaRdson, D.J. \& B.B.NickOL. 1995. The genus Centrorhynchus (Acanthocephala) in North America with description of Centrorhynchus robustus sp. nov., redescription of Centrorhynchus conspectus, and a key to species. Journal of Parasitology, Lawrence, 81 (5): 767-772.

Rodrigues, H.O. 1970. Estudo da fauna helmintológica de "Hemidactylus mabouia" (M. de J.) no Estado da Guanabara. Atas da Sociedade Biologia do Rio de Janeiro, Rio de Janeiro, 12 (Supl.): 15-23. 
SchмiDt, G.D. 1985. Development and life cycles, p. 273-305.In: D.W.T. Crompton \& B.B. Nickol (Eds.). Biology of the Acanthocephala. Cambridge, Cambridge University Press, $\mathrm{XI}+519 \mathrm{p}$.

Seidenberg, A.J. 1973. Ecology of the acanthocephalan, Acanthocephalus dirus (Van Cleave, 1931), in its intermediate host, Asellus intermedius Forbes (Crustacea: Isopoda). Journal of Parasitology, Lawrence, 59 (6): 957-962.

SidDikov, B. Kh. 1987. Woodlice as the intermediate hosts of helminths, p. 95-104. In: T.A. Tulaganov (Ed.). Helminths as Components of Land Biocoenosis of Uzbekistan. Tashkent, Izdatel'tsvoo FAN (in Russian), 151p.
Torres, P. \& S. Puga. 1996. Occurrence of cystacanths of Centrorhynchus sp. (Acanthocephala: Centrorhynchidae) in toads of the genus Eupsophus in Chile. Memórias do Instituto Oswaldo Cruz, Rio de Janeiro, 91 (6): 717-719.

Travassos, L. 1926. Contribuições para o conhecimento da fauna helminthologica brasileira. XX Revisão dos Acanthocephalos brasileiros. Parte II. Familia Echinorhynchidae Hamann, 1892, sub-fam. Centrorhynchinae Travassos, 1919. Memórias do Instituto Oswaldo Cruz, Rio de Janeiro, 19 (1): 31-125.

Yamaguti, S. 1963. Systema Helminthum. Acanthocephala. New York, Interscience Publishers, vol. 5, VII+423p.

Received in 20.VI.2003; accepted in 17.XI.2003.

Revista Brasileira de Zoologia 20 (4): 711-716, dezembro 2003 